\title{
TP53, SPOP and PIK3CA Genes Status in Prostate Cancer
}

\author{
Mazhar Salim Al Zoubi ${ }^{1 *}$, Raed Otoum², Mohammed S Alorjani ${ }^{3}$, Samir Al \\ Bashir $^{3}$, Bahaa Al Trad ${ }^{2}$, Manal Issam Abualrja', Sohaib M Al-Khatib ${ }^{3}$, Khalid \\ Al-Batayneh ${ }^{2}$
}

\begin{abstract}
Recent advances in molecular biology make the identification of prostate cancer (PC) subsets a priority for more understanding of the molecular pathogenesis and treatment options. Genetic alterations in many genes such as TP53, $S P O P$ and $P I K 3 C A$ genes have been reported in $\mathrm{PC}$ with variable frequencies worldwide. We aimed to investigate genetic alterations in the hotspot lesions of TP53, SPOP and PIK3CA genes by direct sequencing and the expression of TP53 and PIK3CA by RT-PCR in prostate cancer, and to explore the correlation between TP53, SPOP and PIK3CA alterations and tumorigenesis of prostate cancer. Seventy-nine FFPE prostate samples from patients who underwent radical prostatectomy were obtained, subjected to genomic DNA extraction and sequenced for mutations in exons 5, 6, 7 and 8 of TP53 gene, exons 4 and 5 of SPOP gene and exons 9 and 20 of PIK3CA gene. RT-PCR was performed for the expression evaluation of the PIK3CA gene. Our results showed a high frequency of TP53 mutations (11/79, $13.9 \%$ ) in the selected population. On the other hand, SPOP and PIK3CA genes did not show any genetic alteration in the sequenced exons. PIK3CA gene overexpression was detected in $6 \%$ of the cohort by RT-PCR. TP53 mutation is the most frequent genetic alteration and likely has a major role in the pathogenesis of PC in the Jordanian population.
\end{abstract}

Keywords: TP53-SPOP-PIK3CA- prostate cancer- p53

Asian Pac J Cancer Prev, 21 (11), 3365-3371

\section{Introduction}

Prostate cancer (PC) is considered the second most common type and the second leading cause of deaths of male cancers and the fourth common type of cancer worldwide (Ferlay et al., 2015; Siegel et al., 2017; Siegel et al., 2019). In Jordan, PC has been estimated to be the fourth most common cancer in males $(8.4 \%)$ and the third cause of death with a $6.2 \%$ mortality rate among males (Abdel-Razeq et al., 2015). Age, family history, race, lifestyle, diet, environmental and genetic factors have been proposed as PC risk factors (Ballon-Landa and Parsons, 2018). To build a clear portrait of PC, intensive molecular investigations are conducted to generate a distinctive molecular profile of $\mathrm{PC}$, however, the molecular pathogenesis of PC is not fully understood (Abeshouse et al., 2015). Voluminous genetic alterations have been proposed and studied to understand the etiology and molecular pathology of prostate cancer. For instance, TP53, SPOP, PIK3CA, BRCA2 and AR genes alterations have been demonstrated in $\mathrm{PC}$ in various populations (Bookstein et al., 1993; Carroll et al., 1993; Taplin et al., 1995; Li et al., 1997; Edwards et al., 2003c; Thomas et al., 2007; Taylor et al., 2010; Barbieri et al., 2012;
Beltran et al., 2013). Despite the presence of different patterns of genetic alterations in these hotspot genes, the fallouts of these studies did not nominate a specific gene alteration in association with the development of PC since different studies showed a variable prevalence of TP53, SPOP and PIK3CA mutations or alterations in the PC cases (Bookstein et al., 1993; Carroll et al., 1993; Mirchandani et al., 1995; Edwards et al., 2003b; Müller et al., 2007; Sun et al., 2009; Taylor et al., 2010; Barbieri et al., 2012; Abeshouse et al., 2015). The presence of the TP53 mutation in PC cell lines shed a light on the impact of the TP53 alterations in the development of PC (Carroll et al., 1993). Further studies showed variable frequencies of TP53 mutations in PC cases (Bookstein et al., 1993; Voeller et al., 1994; Mirchandani et al., 1995; Thomas et al., 2007; Barbieri et al., 2012; Abeshouse et al., 2015). As well, mutations in the SPOP (Speckle-type POZ protein) gene have been also detected in PC cases with variable prevalence (Barbieri et al., 2012; Blattner et al., 2014; Abeshouse et al., 2015). Besides, the PIK3CA gene alteration is highly prevalent in many types of cancers such as endometrial, breast, ovarian, colorectal and prostate cancers (Campbell et al., 2004; Samuels et al., 2004; Oda et al., 2005; Taylor et al., 2010). Therefore, identification

${ }^{1}$ Department of Basic Medical Sciences, Faculty of Medicine, Yarmouk University, Irbid 211-63, Jordan. ${ }^{2}$ Department of Biological Sciences, Faculty of Science, Yarmouk University, Irbid 211-63, Jordan. ${ }^{3}$ Departments of Pathology and Microbiology, Faculty of Medicine, Jordan University of Science and Technology, Irbid, Jordan. *For Correspondence: mszoubi@yu.edu.jo 
of molecular idiosyncratic subsets of PC is the ultimate goal for more understanding the molecular pathology and treatment regimen.

Consequently, the present study was conducted to investigate the role of genetic alterations in TP53, SPOP and $P I K 3 C A$ genes in prostate cancer of a Jordanian cohort. We aimed to perform direct sequencing for the hotspot mutations in exons 5, 6, 7 and 8 of the TP53 gene, exons 9 and 20 of $P I K 3 C A$ gene and exons 4 and 5 of $S P O P$ gene. Moreover, the expression level of PIK3CA gene was assessed by RT-PCR.

\section{Materials and Methods}

\section{Tumor Samples and Patients}

Sample collection and acquiring data were performed after obtaining the institutional review board (IRB) approval from King Abdullah University Hospital (KAUH) at Jordan University of Science and Technology, Irbid (IRB \#: 13/1/881 and Hospital Policy: GM7601).

Formalin-Fixed Paraffin-Embedded (FFPE) tissue samples from $79 \mathrm{PC}$ patients who underwent prostatectomy were provided by the Department of Pathology at KAUH from January 2003 through December 2015. The tissue diagnoses were submitted based on a pathologic assessment of physicians who requested the assays and were further verified by a pathologist at the Department of Pathology. We specifically chose samples from the primary tumor of each original specimen where cancer cells were identified. Macrodissection was performed only on a single representative block from the primary tumor. The majority of the samples showed tumor component of over $60 \%$. The mean age of the enrolled patients with PC was 72 years (55-95 years).

\section{DNA Extraction}

Genomic DNA was extracted from (FFPE) by using the QIAmp extraction DNA kit (Qiagen GmbH, Hilden, Germany) according to the manufacturer's protocols. Briefly, five FFPE sections were collected in $1.5 \mathrm{~mL}$ Eppendorf tubes. Deparaffinization and clearing process was conducted using xylene (3 times) and ethanol incubation (2 times), spinning and drying. The last precipitate was incubated with the lysis buffer, incubated for two hours, followed by column wash and finally eluted with elution buffer. All eluents were stored in $-80^{\circ} \mathrm{C}$ until use. The purity of DNA was estimated by using Nano-drop and confirmed by $0.5 \%$ agarose gel electrophoresis and DNA samples were stored at $-20^{\circ} \mathrm{C}$ for long time storage for further analysis.

\section{Polymerase Chain Reaction (PCR)}

The PCR amplifications targeting exons 5, 6, 7 and 8 of TP53 gene, exons 4 and 5 of SPOP gene and exons 9 and 20 of $P I K 3 C A$ gene were performed using specific sets of primers for the detection of any point mutations based on the NCBI gene sequences (Table 1).

The PCR amplification reaction was performed in a total reaction volume of $30 \mu \mathrm{L}$ using $2 \mathrm{X}$ ready to use a master mix from (New England BioLabs, USA). The PCR reaction was conducted in Gene Pro thermal cycler model TC-E-96G (Bioer, China) under the following cycling conditions: Initial denaturation at $94^{\circ} \mathrm{C}$ for 3 minutes; 40 cycles of $94^{\circ} \mathrm{C}$ denaturation for 30 seconds, $\mathrm{Tm}^{\circ} \mathrm{C}$ annealing for 30 seconds, $68^{\circ} \mathrm{C}$ extension for 60 seconds; followed by final extension at $68^{\circ} \mathrm{C}$ for 5 minutes. PCR products were analyzed and resolved by running the samples on $1.5 \%$ agarose gel.

\section{DNA Sequencing}

Sanger DNA sequencing was performed by external service by (GENEWIZ, NJ, USA). The output of the DNA sequencing service was analyzed by Mutation Surveyor V5.1.1 and FinchTV 1.5. When the sample shows a mutation it was repeated in duplicate in a separate run by performing a PCR and Sanger sequencing.

\section{RNA Extraction, cDNA synthesis and $q R T-P C R$}

RNA extraction was performed by total RNA purification kit from (Jena Bioscience, Germany). Then, the cDNA was produced by following the manufacturer's instructions using RevertAid First Strand cDNA Synthesis Kit from (Thermo Scientific, Lithuania). Finally, the qRT-PCR was conducted using Maxima SYBR Green qPCR Master Mix (2X) kit from (Thermo Scientific), while the amplification was performed on LineGene 9600 Plus thermal cycler from (Bioer, China). The qRT-PCR analysis was performed by using $2^{-\Delta C t}$ calculation relative to the $\beta$-actin reference gene using the following primers (PIK3CA: F-5' - GGCCACTGTGGTTGAATTGGG -3', R-5' - AGTGCACCTTTCAAGCCGCC -3'), ( $\beta$-actin: F-5' - GAA CGG TGA AGG TGA CAG -3', R-5' - TTT AGG ATG GCA AGG GAC T -3').

\section{Results}

Seventy-nine PC samples were screened for mutations in exons 5, 6, 7 and 8 of TP53 gene (NG_017013) (HGNC: 11998), exons 4 and 5 of SPOP (NG_041815) (HGNC:11254) gene and exons 9 and 20 of PIK3CA (NG_012113)(HGNC:8975) gene. The clinicopathological data of patients are represented in Table 2.

The current results showed a substantial frequency of mutations in the TP53 gene $(13.9 \%, 11 / 79)$ as shown in Table 3. Missense mutations in the TP53 gene were detected in nine samples as the followings: four substitutional mutations were detected in exon 5 (A138T, L145P, 2 C176Y) and one substitutional mutation in intron $5(\mathrm{C} 12351 \mathrm{~T})$, one substitutional mutation was detected in exon 6 (L194R), two substitutional mutations were detected in exon 7 (Y234N), and one substitutional mutation was detected in exon 8 (R273C). In addition, a termination mutation was detected in exon 6 (R196X). Finally, a silent mutation was detected in exon 6 (R213R). A sample of detected mutations is presented in Figure 1. The detailed description of the detected mutations is illustrated in Table 3.

On the other hand, our findings did not show any mutation in exons 4 and 5 of SPOP gene and exons 9 and 20 of PIK3CA gene. Also, the RT-PCR analysis showed overexpression in $6 \%$ of the $P I K 3 C A$ gene in the selected samples. 
Table 1. The Set of Primers Used to Detect the Point Mutations on Exon 5, 6, 7 and 8 of the TP53 Gene, Exon 4 and 5 of SPOP Gene, and Exon 9 and 20 of PIK3CA Gene

\begin{tabular}{|c|c|c|c|c|}
\hline Target Gene & Exon & Forward primer & Reverse primer & $\operatorname{Tm}\left({ }^{\circ} \mathrm{C}\right)$ \\
\hline \multirow[t]{4}{*}{ TP53 } & 5 & F- 5'CAC TTG TGC CCT GAC TTT CAA C-3' & R- 5'- CAA CCA GCC CTG TCG TCT CTC -3' & 56 \\
\hline & 6 & F- 5'-TCC CCA GGC CTC TGA TTC CT-3' & R- 5'- CCT TAA CCC CTC CTC CCA GA -3' & 56 \\
\hline & 7 & F- 5'- GCC TCA TCTTGG GCC TGTGTTATC-3' & R- 5'- TCA GAG GCA AGC AGA GGC TG -3' & 56 \\
\hline & 8 & F- 5'-CTGATTTCCTTACTGCCTCTTGC -3' & R- 5'- TCTCCTCCACCGCTTCTTGTC -3' & 56 \\
\hline \multirow[t]{2}{*}{$S P O P$} & 4 & F-5'-ACCCATAGCTTTGGTTTCTTCTCCC-3' & R-5'-TATCTGTTTTGGACAGGTGTTTGCG-3' & 60 \\
\hline & 5 & F-5'-ACTCATCAGATCTGGGAACTGC-3' & R-5'-AGTTGTGGCTTTGATCTGGTT-3' & 60 \\
\hline \multirow[t]{4}{*}{$P I K 3 C A$} & 9 & 5'-CTGTGAATCCAGAGGGGAAA-'3 & 5'-CCACAAATATCAATTTACAACCATTG-'3 & 55 \\
\hline & 9 & 5'-AATCCAGAGGGGAAAAATATGA-'3 & 5'-TGAGATCAGCCAAATTCAGTTA-'3 & 55 \\
\hline & 20 & 5'-GCTTTGTCTACGAAAGCCTCTCT-'3 & 5'-ATACATTCGAAAGACCCTAGCCC-'3 & 60 \\
\hline & 20 & 5'-ATGATGCTTGGCTCTGGAAT-'3 & 5'-ACTCTCAGCAGGCAAAGACC-'3 & 60 \\
\hline
\end{tabular}

\section{Discussion}

Structural and functional alterations in an immense number of genes have been found in PC tissues involving germline, somatic and mitochondrial genetic alterations (Dong, 2006). However, due to variable prevalence in these mutations in PC, there is a need for more genetic studies to identify the molecular portrait of PC. Therefore, we aimed to investigate genetic alteration in the most predominant genetically mutated genes; TP53, SPOP and $P I K 3 C A$ in most cancers.

The p53 transcription factor has a central role in the induction of cell suicide process in response to DNA damage or oncogenesis activation (Sherr and McCormick, 2002). Therefore, alterations in the TP53 gene are expected to be associated with the development of several cancers, including PC. Our results showed a distinctive pattern of genetic alteration in the Jordanian PC which was demonstrated by the presence of TP53 mutation in $13.9 \%$ of the studied population. The detected TP53 mutations were found in exons 5, 6, 7 and 8. Genetic alterations

Table 2. Clinicopathological Data of the Patients

\begin{tabular}{lcc}
\hline Clinicopathological data $(\mathrm{n}=79)$ & \\
Age (years) & 72 & \\
PSA (ug/L) & 61.6 & $\%$ \\
\hline Gleason Score & $\mathrm{n}$ & $13 \%$ \\
$3+3$ & 10 & $25 \%$ \\
$3+4$ & 20 & $4 \%$ \\
$4+3$ & 3 & $13 \%$ \\
$4+4$ & 10 & $26 \%$ \\
$4+5$ & 21 & $4 \%$ \\
$5+4$ & 3 & $15 \%$ \\
$5+5$ & 12 & \\
\hline
\end{tabular}

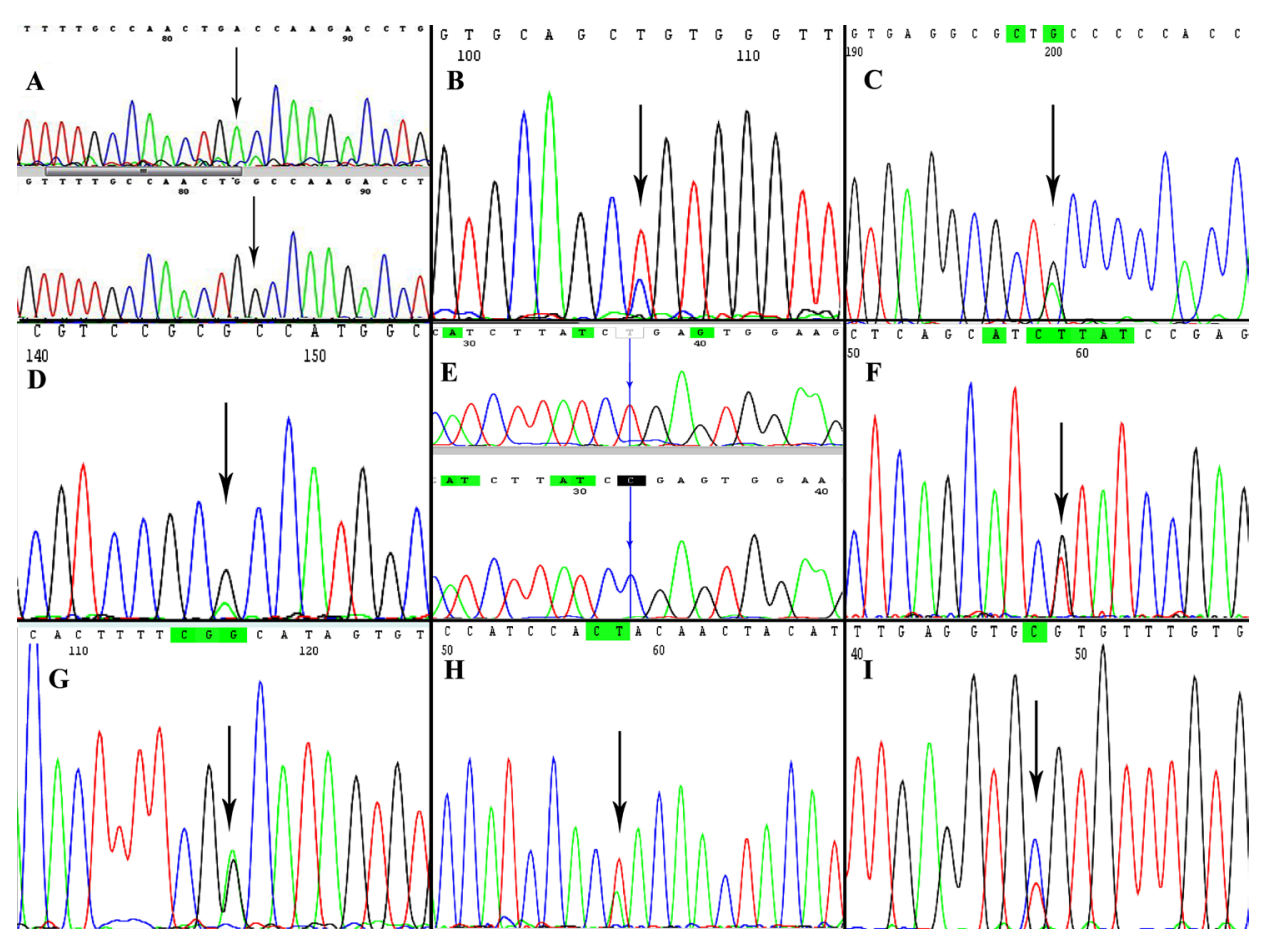

Figure 1. A Representative Chromatogram of the Detected Mutations in the TP53 Gene. A: Homologous mutation GCC/ACC (A1358T) (exon 5), B: CTG/CCG (L145P) (exon 5), C: TGC/TAC (C176Y) (exon 5), D: Rs868157297 (G/GA) (intron 4), E: Homologous mutation CGA/TGA (R196*) (exon 6), F: CTT/CGT (L194R) (exon 6), G: CGA/ CGG (R213R) (exon 6) H: TAC/AAC (Y234N) (exon 7), I: CGT/TGT (R273C) (exon 8). 
Table 3. Mutation Frequency in the TP53 Gene in the Prostate Samples

\begin{tabular}{|c|c|c|c|c|c|c|}
\hline Gene & Exon \# & $\begin{array}{l}\text { Point } \\
\text { mutation }\end{array}$ & bp substitution & Genomic Mutation ID & Mutation (CDS) & Common in \\
\hline \multirow[t]{10}{*}{ TP53 } & \multirow[t]{5}{*}{5} & A138T & $\begin{array}{l}\text { GCC/ACC } \\
(12400)\end{array}$ & COSV52839281 & c. $412 \mathrm{G}>\mathrm{A}$ & $\begin{array}{l}\text { Breast Cancer (Maitra et al., 1999), } \\
\text { Oral Squamous Carcinoma(Sakata, } \\
\text { 1996) }\end{array}$ \\
\hline & & L145P & $\begin{array}{l}\text { CTG/CCG } \\
(12422)\end{array}$ & COSV52676080 & c. $434 \mathrm{~T}>\mathrm{C}$ & $\begin{array}{l}\text { Colorectal Cancer(Yuen et al., 1997), } \\
\text { Breast Cancer (Umekita et al., 1994), } \\
\text { Ovarian Cancer (Fallows et al., 2001) }\end{array}$ \\
\hline & & $2 \mathrm{C} 176 \mathrm{Y}$ & $\begin{array}{l}\text { TGC/TAC } \\
(12515)\end{array}$ & COSV52660760 & c. $527 \mathrm{G}>\mathrm{A}$ & $\begin{array}{l}\text { Colorectal Cancer(Onda et al., 1997; } \\
\text { Yuen et al., 1997), Lung Cancer } \\
\text { (Husgafvel-Pursiainen et al., 2000) } \\
\text { Breast Cancer (Falette et al., 1998) }\end{array}$ \\
\hline & & $\mathrm{C} / \mathrm{CT}$ & $\mathrm{C} / \mathrm{CT}$ & rs868137297 & $\mathrm{C} / \mathrm{CT}$ & $\begin{array}{l}\text { Anaplastic rhabdomyosarcoma, } \\
\text { (Hettmer et al., 2014) Li-Fraumeni } \\
\text { syndrome }\end{array}$ \\
\hline & & & -12351 & $\begin{array}{l}\text { NM_000546.5(TP53):c.376- } \\
\text { 1G>A AND Ovarian } \\
\text { Neoplasms }\end{array}$ & NG_017013.2:g.17314G $>A$ & $\begin{array}{l}\text { (Villani et al., 2016) and ( } \mathrm{Li} \text { et al., } \\
\text { 2019), Breast cancer (Li et al., 2019). }\end{array}$ \\
\hline & \multirow[t]{3}{*}{6} & L194R & $\begin{array}{l}\text { CTT/CGT } \\
(12650)\end{array}$ & COSV52679257 & c. $581 \mathrm{~T}>\mathrm{G}$ & $\begin{array}{l}\text { Breast(Andersen et al., 1993) and } \\
\text { lung(Suzuki et al., 1992) }\end{array}$ \\
\hline & & R196* & $\begin{array}{l}\text { CGA homo TGA } \\
(12655)\end{array}$ & COSV52663748 & c. $586 \mathrm{C}>\mathrm{T}$ (Homologus) & $\begin{array}{l}\text { Gastric Cancer(Poremba et al., } \\
\text { 1995), breast (Chappuis et al., 1999) } \\
\text { Esophagus(Audrezet et al., 1993), } \\
\text { Skin Cancer (Moles et al., 1993) }\end{array}$ \\
\hline & & R213R & $\begin{array}{l}\text { CGA/CGG } \\
(12708)\end{array}$ & & c. $639 \mathrm{~A}>\mathrm{G}$ & $\begin{array}{l}\text { CNS (Ohgaki et al., 1993) Biliary } \\
\text { tract (Wardell et al., 2018), Colorec- } \\
\text { tal Cancer (Ashktorab et al., 2017) }\end{array}$ \\
\hline & 7 & $2 \mathrm{Y} 234 \mathrm{~N}$ & $\begin{array}{l}\text { TAC/AAC } \\
(13337)\end{array}$ & COSV52730114 & c. $700 \mathrm{~T}>\mathrm{A}$ & $\begin{array}{l}\text { Prostate cancer(Konishi et al., 1995), } \\
\text { B-cell lymphoma (Zhang et al., } \\
\text { 2013), and breast cancer(Van Em- } \\
\text { burgh et al., 2008) }\end{array}$ \\
\hline & 8 & $\mathrm{R} 273 \mathrm{C}$ & $\begin{array}{l}\text { CGT/TGT } \\
(13797)\end{array}$ & COSV52662066 & c. $817 \mathrm{C}>\mathrm{T}$ & $\begin{array}{l}\text { Colorectal cancer(Ishioka et al., } \\
\text { 1991), hepatocellular carcinoma } \\
\text { (Kress et al., 1992), Esophageal car- } \\
\text { cinoma (İmazeki et al., 1992) }\end{array}$ \\
\hline
\end{tabular}

in TP53, as a tumor suppressor oncogene, have been reported as a predominant mutated gene in many cancers (Bookstein et al., 1993; Carroll et al., 1993; Mirchandani et al., 1995; Sherr and McCormick, 2002; Dong, 2006; Kandoth et al., 2013). In 1992, Effert et al, reported the presence of point mutation in codon 172 of TP53 gene (Effert et al., 1992). Then, propagation in TP53 genetic studies showed a presence of various prevalence of TP53 mutations in different populations ranging from 2 to $65 \%$ (Hall et al., 1995; Hughes et al., 1995; Kubota et al., 1995; Gumerlock et al., 1997; Theodorescu et al., 1997; Kluth et al., 2014). Moreover, some studies showed an association between TP53 mutations and the advanced stages of PC (Bookstein et al., 1993; Abate-Shen and Shen, 2000). While other studies demonstrated a frequently expressed transition mutations (Chi et al., 1994). Underscoring the importance of p53 pathway, a mutation in CHEK2, an upstream regulator of $\mathrm{p} 53$, has also been found to be frequent in PC development (Dong et al., 2003).

Oncogenic mutations in TP53 have been shown in different cancer cell lines which may involve invasion, migration, propagation of cell cycle, drug resistance, anchorage-independent growth, increased colony formation, polyploidy and angiogenesis (Effert et al., 1992; Muller and Vousden, 2014). The presence of TP53 mutation pattern in $\mathrm{PC}$ can be a worthy diagnostic tool for the identification of a subset of patients that may undergo a treatment regimen since some studies showed a role of mutant TP53 in the signaling pathways such as RTK
(Adorno et al., 2009; Sauer et al., 2010; Wang et al., 2013). Here, we identified eleven point-mutations in the DNA binding domain of the TP53 gene that has been reported in previous studies. Specifically, A138T mutation was reported in lung and gastric cancers (Bumroongkit et al., 2008; Shimizu et al., 2014), L145P mutation was reported in breast cancer (Greenblatt et al., 2001), C176Y mutation was reported in ovarian cancer, L194R was reported in lung cancer (Ko et al., 2002), R196* was described as a truncated mutation the produces a pro-tumorigenic isoforms and reported in colon cancer (Shirole et al., 2016), Y234N was associated with prostate cancer (Konishi et al., 1995) and breast cancer (Van Emburgh et al., 2008), R273C and gastric cancer(Renault et al., 1993) and hepatocellular carcinoma (Kress et al., 1992).

It is believed that TP53 mutations are associated with the metastasis and progression of PC (Eastham et al., 1995; Dong, 2006; Ecke et al., 2010). As a limitation of our study, the clinical data of the patients were not available for the follow-up because most of them were referred to the central cancer centre (King Hussain Cancer Center, Amman). However, other genetic alterations in the TP53 gene for the same population are highly recommended to be investigated by exome sequencing to generate a clear molecular portrait of the TP53 gene in the Jordanian PC patients.

On the other hand, SPOP and PIK3CA genes did not show any mutation or a variation in the gene expression at the level of mRNA. SPOP gene mutation has been 
reported as one of the most frequents alterations in $\mathrm{PC}$ (Barbieri et al., 2012; Abeshouse et al., 2015). Abeshouse et al, in a molecular taxonomy study, have reported a mutation in the SPOP gene in $11 \%$ of primary PC samples (Abeshouse et al., 2015). A diverse population cohorts showed variable prevalence of SPOP mutations in PC (4.6\% - 14.4\%) (Blattner et al., 2014). The whole-exome sequencing of multiple cohorts showed SPOP mutations in $6-15 \%$ of primary and metastatic PC (Barbieri et al., 2012). Another study conferred the role of mutated SPOP gene in the resistance of PC treatment (Dai et al., 2017). Furthermore, Gunther et al demonstrated the role of SPOP mutations in the genomic instability in PC (Boysen et al., 2015). The inconsistency of our findings with the previous reports can be attributed to the different exons that have been studied. Therefore, it is recommended to screen the rest exons in the same population. Our findings did not exclude the possible role of SPOP in the development of PC since we sequenced only two exons (4 and 5) of the SPOP gene. Therefore, further genetic studies by exome sequencing are required to investigate the prevalence of SPOP mutations in PC of the Jordanian population.

$P I K 3 C A$ oncogenic alteration in many cancers derived the hypothesis of its role in the development of PC. Genomic alterations of the PI3K-AKT signaling pathway have been reported in many diverse solid tumors including endometrial, colorectal, cervical, Salivary gland, breast, gastric, ovarian and prostate cancers (Bachman et al., 2004; Samuels et al., 2004; Levine et al., 2005; Sun et al., 2009; Arsenic et al., 2014; Millis et al., 2016). Three studies have reported PIK3CA alterations in PC (Edwards et al., 2003a; Müller et al., 2007; Sun et al., 2009). Two of them described PIK3CA amplification and only the most recent study by Sun et al., (2009) has found for the first time $P I K 3 C A$ mutations in exon 9 in one sample representing $3 \%$ of prostate tumors. Consistently, our findings support the rare incidence of $P I K 3 C A$ mutations and overexpression in a subset of PC cases $(6 \%)$ compared to a previous study that reported about $13 \%$ of the cases (Sun et al., 2009). The oncogenic influence can be stimulated through gene amplification, point mutation, and translocation (Nathanson et al., 2001). A point mutation may not be the main pathway to activate PIK3CA gene in PC in this study. PI3Ks signaling pathway also has many other components besides PIK3CA gene which ultimately results in the activation of PI3K-AKT signaling pathway. The current data, together with other studies are not demonstrating the involvement of PIK3CA mutation in $\mathrm{PC}$, however, other components of the PI3K pathway in these tumors may be involved in PC tumorigenesis and suggest that the PI3K pathway may exhibit a valuable target for the development of novel therapies for this type of cancer.

Tumor growth and development is a multifactorial disorder, which requires a multistep process involving many cell processes that include signal transduction, cell metabolism and cell cycling. One of the most important mechanisms that in turn plays a role in activating oncogenes or inactivating tumor suppressor genes is gene aberration. Jordanian differences in genetic makeup, smoking consumption, diet habits, and other unidentified cultural factors may also be responsible for the disparity. The diverse pathological and etiological factors of PCs in different geographical locations may be paralleled by differences in the molecular pathway of tumor development.

The lack of mutations in PIK3CA in the current cohort of $\mathrm{PC}$ articulates that mutations in this gene are not a key element in PC pathogenesis in the Jordanian population. This reveals that $P I K 3 C A$ gene mutation is not the primary molecular mechanism in activating the PIK3/AKT-driven tumorigenesis pathway in PC. These results show a quite good congruence with previously published studies, most of them based on a smaller number of cases or not precisely defining the clinicopathological features of the samples but in our study, we have selected a larger, welldefined group of patients.

Since the current study is only constricted on a radical prostatectomy sample from different Gleason scores, further studies involving PC biopsies from different patients may be able to address the TP53, SPOP and $P I K 3 C A$ mutations in PC. Our study was biased only for radical prostatectomy samples due to the low sample volume of biopsies in the department of pathology which may limit our study. Recent integrative genomic profiling has identified the RB, PI3K and RAS/RAF as the most commonly altered pathways in primary and metastatic PC (Taylor et al., 2010).

In conclusion, in the present study, we analyzed exclusively 79 consecutive patients of Jordanian origin with prostate cancer mainly at advanced stages and we reported TP53 mutations in $11.9 \%$ of the patients and absence of SPOP and PIK3CA mutations in the study population. It is possible that more precise results could be obtained from a study with a larger sample size. Thus, further studies with larger sample size are necessary to compare the site-specific frequencies and define any potential role of these mutations in the development of prostate cancer. Therefore, according to our findings, it is unlikely that in Jordanian population SPOP and PIK3CA hotspot mutations contribute to prostate cancer or they do but in a much lower percentage. Other mechanisms of PIK3CA activation or mutations of other molecular pathways could be involved in the pathogenesis of the disease.

\section{Acknowledgements}

We are very thankful to the Deanship of Scientific Research and Graduate Studies at Yarmouk University for financial support to complete this work. And we thank the Department of Pathology at King Abdullah University Hospital for the valuable help and support. Special thanks to Mr. Adel Rababah for his help in the figures production.

\section{References}

Abate-Shen C, Shen MM (2000). Molecular genetics of prostate cancer. Genes Dev, 14, 2410-34.

Abdel-Razeq H, Attiga F, Mansour A (2015). Cancer care in Jordan. Hematol Oncol Stem Cell Ther, 8, 64-70.

Abeshouse A, Ahn J, Akbani R, et al (2015). The molecular 
taxonomy of primary prostate cancer. Cell, 163, 1011-25.

Adorno M, Cordenonsi M, Montagner M, et al (2009). A Mutant-p53/Smad complex opposes p63 to empower TGF $\beta$ induced metastasis. Cell, 137, 87-98.

Andersen T, Holm R, Nesland J, et al (1993). Prognostic significance of TP53 alterations in breast carcinoma. $\mathrm{Br} \mathrm{J}$ Cancer, 68, 540.

Arsenic R, Lehmann A, Budczies J, et al (2014). Analysis of PIK3CA mutations in breast cancer subtypes. Appl Immunohistochem Mol Morphol, 22, 50-6.

Ashktorab H, Mokarram P, Azimi H, et al (2017). Targeted exome sequencing reveals distinct pathogenic variants in Iranians with colorectal cancer. Oncotarget, 8, 7852.

Audrezet M, Robaszkiewicz M, Mercier B, et al (1993). TP53 gene mutation profile in esophageal squamous cell carcinomas. Cancer Res, 53, 5745-9.

Bachman KE, Argani P, Samuels Y, et al (2004). The PIK3CA gene is mutated with high frequency in human breast cancers. Cancer Biol Ther, 3, 772-5.

Ballon-Landa E, Parsons JK (2018). Nutrition, physical activity, and lifestyle factors in prostate cancer prevention. Curr Opin Urol, 28, 55-61.

Barbieri CE, Baca SC, Lawrence MS, et al (2012). Exome sequencing identifies recurrent $S P O P$, FOXA1 and MED12 mutations in prostate cancer. Nat Genet, 44, 685.

Beltran H, Yelensky R, Frampton GM, et al (2013). Targeted nextgeneration sequencing of advanced prostate cancer identifies potential therapeutic targets and disease heterogeneity. Eur Urol, 63, 920-6.

Blattner M, Lee DJ, O'Reilly C, et al (2014). SPOP mutations in prostate cancer across demographically diverse patient cohorts. Neoplasia, 16, 14-W0.

Bookstein R, MacGrogan D, Hilsenbeck SG, et al (1993). p53 is mutated in a subset of advanced-stage prostate cancers. Cancer Res, 53, 3369-73.

Boysen G, Barbieri CE, Prandi D, et al (2015). SPOP mutation leads to genomic instability in prostate cancer. Elife, 4, e09207.

Bumroongkit K, Rannala B, Traisathit P, et al (2008). TP53 gene mutations of lung cancer patients in upper northern Thailand and environmental risk factors. Cancer Genet Cytogenet, 185, 20-7.

Campbell IG, Russell SE, Choong DY, et al (2004). Mutation of the PIK3CA gene in ovarian and breast cancer. Cancer Res, 64, 7678-81.

Carroll AG, Voeller HJ, Sugars L, et al (1993). p53 oncogene mutations in three human prostate cancer cell lines. Prostate, 23, 123-34.

Chappuis PO, Estreicher A, Dieterich B, et al (1999). Prognostic significance of p53 mutation in breast cancer: Frequent detection of non-missense mutations by yeast functional assay. Int J Cancer, 84, 587-93.

Chi S-G, deVere White RW, Meyers FJ, et al (1994). p53 in prostate cancer: frequent expressed transition mutations. J Natl Cancer Inst, 86, 926-33.

Dai X, Gan W, Li X, et al (2017). Prostate cancer-associated SPOP mutations confer resistance to BET inhibitors through stabilization of BRD4. Nat Med, 23, 1063.

Dong JT (2006). Prevalent mutations in prostate cancer. JCB, 97, 433-47.

Dong X, Wang L, Taniguchi K, et al (2003). Mutations in CHEK2 associated with prostate cancer risk. Am J Hum Genet, 72, 270-80.

Eastham JA, Stapleton A, Gousse AE, et al (1995). Association of p53 mutations with metastatic prostate cancer. Clin Cancer Res, 1, 1111-8.

Ecke TH, Schlechte HH, Schiemenz K, et al (2010). TP53 gene mutations in prostate cancer progression. Anticancer Res, 30, 1579-86.

Edwards J, Krishna NS, Witton CJ, et al (2003b). Gene amplifications associated with the development of hormone-resistant prostate cancer. Clin Cancer Res, 9, 5271-81.

Edwards SM, Kote-Jarai Z, Meitz J, et al (2003c). Two percent of men with early-onset prostate cancer harbor germline mutations in the BRCA2 gene. Am J Hum Genet, 72, 1-12.

Effert PJ, Neubauer A, Walther PJ, et al (1992). Alterations of the p53 gene are associated with the progression of a human prostate carcinoma. J Urol, 147, 789-93.

Falette N, Paperin M-P, Treilleux I, et al (1998). Prognostic value of p53 gene mutations in a large series of node-negative breast cancer patients. Cancer Res, 58, 1451-5.

Fallows S, Price J, Atkinson R, et al (2001). P53 mutation does not affect prognosis in ovarian epithelial malignancies. J Pathol, 194, 68-75.

Greenblatt MS, Chappuis PO, Bond JP, et al (2001). TP53 mutations in breast cancer associated with BRCA1 or BRCA2 germ-line mutations: distinctive spectrum and structural distribution. Cancer Res, 61, 4092-7.

Gumerlock PH, Chi S-G, Shi X-B, et al (1997). p53 abnormalities in primary prostate cancer: single-strand conformation polymorphism analysis of complementary DNA in comparison with genomic DNA. J Natl Cancer Inst, 89, 66-71.

Hall MC, Navone NM, Troncoso P, et al (1995). Frequency and characterization of p53 mutations in clinically localized prostate cancer. Urology, 45, 470-5.

Hettmer S, Archer NM, Somers GR, et al (2014). Anaplastic rhabdomyosarcoma in TP53 germline mutation carriers. Cancer, 120, 1068-75.

Hughes JH, Cohen MB, Robinson RA (1995). p53 immunoreactivity in primary and metastatic prostatic adenocarcinoma. Mod Pathol, 8, 462-6.

Husgafvel-Pursiainen K, Boffetta P, Kannio A, et al (2000). p53 mutations and exposure to environmental tobacco smoke in a multicenter study on lung cancer. Cancer Res, 60, 2906-11.

İmazeki F, Omata M, Nose H, et al (1992). p53 gene mutations in gastric and esophageal cancers. Gastroenterology, 103, 892-6.

Ishioka C, Sato T, Gamoh M, et al (1991). Mutations of the p53 gene, including an intronic point mutation, in colorectal tumors. Biochem Biophys Res Commun, 177, 901-6.

Kandoth C, McLellan MD, Vandin F, et al (2013). Mutational landscape and significance across 12 major cancer types. Nature, 502, 333.

Kluth M, Harasimowicz S, Burkhardt L, et al (2014). Clinical significance of different types of p53 gene alteration in surgically treated prostate cancer. Int J Cancer, 135, 1369-80.

Ko J-L, Chiao M-C, Chang S-L, et al (2002). A novel p53 mutant retained functional activity in lung carcinomas. DNA Repair, 1, 755-62.

Konishi N, Hiasa Y, Hayashi I, et al (1995). p53 mutations occur in clinical, but not latent, human prostate carcinoma. Jpn $J$ Cancer Res, 86, 57-63.

Kress S, Jahn U-R, Buchmann A, et al (1992). p53 mutations in human hepatocellular carcinomas from Germany. Cancer Res, 52, 3220-3.

Kubota Y, Shuin T, Uemura H, et al (1995). Tumor suppressor gene p53 mutations in human prostate cancer. Prostate, 27, 18-24.

Levine DA, Bogomolniy F, Yee CJ, et al (2005). Frequent mutation of the PIK3CA gene in ovarian and breast cancers. Clin Cancer Res, 11, 2875-8.

Li J, Yen C, Liaw D, et al (1997). PTEN, a putative protein 
tyrosine phosphatase gene mutated in human brain, breast, and prostate cancer. Science, 275, 1943-7.

Li JY, Jing R, Wei H, et al (2019). Germline mutations in 40 cancer susceptibility genes among $\mathrm{C}$ hinese patients with high hereditary risk breast cancer. Int J Cancer, 144, 281-9.

Maitra A, Tavassoli FA, Albores-Saavedra J, et al (1999). Molecular abnormalities associated with secretory carcinomas of the breast. Hum Pathol, 30, 1435-40.

Millis SZ, Ikeda S, Reddy S, et al (2016). Landscape of phosphatidylinositol-3-kinase pathway alterations across 19 784 diverse solid tumors. JAMA Oncol, 2, 1565-73.

Mirchandani D, Zheng J, Miller GJ, et al (1995). Heterogeneity in intratumor distribution of $\mathrm{p} 53$ mutations in human prostate cancer. Am J Pathol, 147, 92.

Moles J, Moyret C, Guillot Be, et al (1993). p53 gene mutations in human epithelial skin cancers. Oncogene, 8, 583-8.

Müller CI, Miller CW, Hofmann W-K, et al (2007). Rare mutations of the PIK3CA gene in malignancies of the hematopoietic system as well as endometrium, ovary, prostate and osteosarcomas, and discovery of a PIK3CA pseudogene. Leuk Res, 31, 27-32.

Muller PA, Vousden KH (2014). Mutant p53 in cancer: new functions and therapeutic opportunities. Cancer Cell, 25, 304-17.

Nathanson KN, Wooster R, Weber BL (2001). Breast cancer genetics: what we know and what we need. Nat Med, 7, 552.

Oda K, Stokoe D, Taketani Y, et al (2005). High frequency of coexistent mutations of PIK3CA and PTEN genes in endometrial carcinoma. Cancer Res, 65, 10669-73.

Ohgaki H, Eibl RH, Reichel MB, et al (1993). Mutations of the p53 tumor suppressor gene in neoplasms of the human nervous system. Mol Carcinog, 8, 74-80.

Onda M, Abe R, Tsuchiya A, et al (1997). K-ras and p53 gene mutations in colorectal cancer in 57 Japanese patients. Fukushima J Med Sci, 43, 29-39.

Poremba C, Schmid K, Böcker W, et al (1995). Frequency and spectrum of $\mathrm{p} 53$ mutations in gastric cancer - a molecular genetic and immunohistochemical study. Virchows Arch, 426, 447-55.

Renault B, Van Den Broek M, Fodde R, et al (1993). Base transitions are the most frequent genetic changes at p53 in gastric cancer. Cancer Res, 53, 2614-7.

Sakata K (1996). Alterations of tumor suppressor genes and the H-ras oncogene in oral squamous cell carcinoma. $J$ Oral Pathol Med, 25, 302-7.

Samuels Y, Wang Z, Bardelli A, et al (2004). High frequency of mutations of the PIK3CA gene in human cancers. Science, 304, 554.

Sauer L, Gitenay D, Vo C, et al (2010). Mutant p53 initiates a feedback loop that involves Egr-1/EGF receptor/ERK in prostate cancer cells. Oncogene, 29, 2628.

Sherr CJ, McCormick F (2002). The RB and p53 pathways in cancer. Cancer Cell, 2, 103-12.

Shimizu T, Marusawa H, Matsumoto Y, et al (2014). Accumulation of somatic mutations in TP53 in gastric epithelium with Helicobacter pylori infection. Gastroenterology, 147, 407-17. e3.

Shirole NH, Pal D, Kastenhuber ER, et al (2016). TP53 exon-6 truncating mutations produce separation of function isoforms with pro-tumorigenic functions. Elife, 5, e17929.

Siegel RL, Miller KD, Jemal A (2017). Cancer statistics, 2017. CA Cancer J Clin, 67, 7-30.

Sun X, Huang J, Homma T, et al (2009). Genetic alterations in the PI3K pathway in prostate cancer. Anticancer Res, 29, 1739-43.

Suzuki H, Takahashi T, Kuroishi T, et al (1992). p53 mutations in non-small cell lung cancer in Japan: association between TP53, SPOP and PIK3CA Genes Status in Prostate Cancer mutations and smoking. Cancer Res, 52, 734-6.

Taplin M-E, Bubley GJ, Shuster TD, et al (1995). Mutation of the androgen-receptor gene in metastatic androgen-independent prostate cancer. N Engl J Med, 332, 1393-8.

Taylor BS, Schultz N, Hieronymus H, et al (2010). Integrative genomic profiling of human prostate cancer. Cancer Cell, 18, 11-22.

Theodorescu D, Broder SR, Boyd JC, et al (1997). p53, bcl-2 and retinoblastoma proteins as long-term prognostic markers in localized carcinoma of the prostate. J Urol, 158, 131-7.

Thomas RK, Baker AC, DeBiasi RM, et al (2007). High-throughput oncogene mutation profiling in human cancer. Nat Genet, 39, 347.

Umekita Y, Kobayashi K, Saheki T, et al (1994). Nuclear accumulation of $\mathrm{p} 53$ protein correlates with mutations in the p53 gene on archival paraffin-embedded tissues of human breast cancer. Jpn J Cancer Res, 85, 825-30.

Van Emburgh BO, Hu JJ, Levine EA, et al (2008). Polymorphisms in drug metabolism genes, smoking, and p53 mutations in breast cancer. Mol Carcinog, 47, 88-99.

Villani A, Shore A, Wasserman JD, et al (2016). Biochemical and imaging surveillance in germline TP53 mutation carriers with Li-Fraumeni syndrome: 11 year follow-up of a prospective observational study. Lancet Oncol, 17, 1295-305.

Voeller J, Sugars LVY, Pretlow T, et al (1994). p53 oncogene mutations in human prostate cancer specimens. J Urol, 151, 492-5.

Wang W, Cheng B, Miao L, et al (2013). Mutant p53-R273H gains new function in sustained activation of EGFR signaling via suppressing miR-27a expression. Cell Death Dis, 4, e574.

Wardell CP, Fujita M, Yamada T, et al (2018). Genomic characterization of biliary tract cancers identifies driver genes and predisposing mutations. J Hepatol, 68, 959-69.

Yuen S, Chung L, Leung S, et al (1997). Colorectal carcinoma in Hong Kong: epidemiology and genetic mutations. $\mathrm{Br} J$ Cancer, 76, 1610.

Zhang J, Grubor V, Love CL, et al (2013). Genetic heterogeneity of diffuse large B-cell lymphoma. Proc Natl Acad Sci US A, 110, 1398-403.

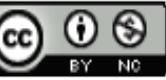

This work is licensed under a Creative Commons AttributionNon Commercial 4.0 International License. 